\title{
Daytime pattern of post-exercise protein intake affects whole-body protein turnover in resistance-trained males
}

\author{
Daniel R Moore ${ }^{1,2^{*}}$, Jose Areta ${ }^{3}$, Vernon G Coffey ${ }^{3}$, Trent Stellingwerff ${ }^{1,2,4}$, Stuart M Phillips ${ }^{5}$, Louise M Burke , \\ Marilyn Cléroux ${ }^{1}$, Jean-Philippe Godin ${ }^{1}$ and John A Hawley ${ }^{3}$
}

\begin{abstract}
Background: The pattern of protein intake following exercise may impact whole-body protein turnover and net protein retention. We determined the effects of different protein feeding strategies on protein metabolism in resistance-trained young men.

Methods: Participants were randomly assigned to ingest either $80 \mathrm{~g}$ of whey protein as $8 \times 10 \mathrm{~g}$ every $1.5 \mathrm{~h}$ (PULSE; $n=8$ ), $4 \times 20$ g every $3 \mathrm{~h}$ (intermediate, INT; $n=7$ ), or $2 \times 40 \mathrm{~g}$ every $6 \mathrm{~h}$ (BOLUS; $\mathrm{n=8}$ ) after an acute bout of bilateral knee extension exercise (4x10 repetitions at 80\% maximal strength). Whole-body protein turnover (Q), synthesis (S), breakdown (B), and net balance (NB) were measured throughout $12 \mathrm{~h}$ of recovery by a bolus ingestion of $\left[{ }^{15} \mathrm{~N}\right]$ glycine with urinary $\left[{ }^{15} \mathrm{~N}\right]$ ammonia enrichment as the collected end-product.

Results: PULSE Q rates were greater than BOLUS $(\sim 19 \%, \mathrm{P}<0.05)$ with a trend towards being greater than INT $(\sim 9 \%$, $\mathrm{P}=0.08$ ). Rates of $\mathrm{S}$ were $32 \%$ and $19 \%$ greater and rates of $\mathrm{B}$ were $51 \%$ and $57 \%$ greater for PULSE as compared to INT and BOLUS, respectively $(P<0.05)$, with no difference between INT and BOLUS. There were no statistical differences in NB between groups ( $P=0.23)$; however, magnitude-based inferential statistics revealed likely small (mean effect $\pm 90 \% \mathrm{Cl} ; 0.59 \pm 0.87)$ and moderate $(0.80 \pm 0.91)$ increases in NB for PULSE and INT compared to BOLUS and possible small increase $(0.42 \pm 1.00)$ for INT vs. PULSE.

Conclusion: We conclude that the pattern of ingested protein, and not only the total daily amount, can impact whole-body protein metabolism. Individuals aiming to maximize NB would likely benefit from repeated ingestion of moderate amounts of protein $(\sim 20 \mathrm{~g})$ at regular intervals $(\sim 3 \mathrm{~h})$ throughout the day.
\end{abstract}

Keywords: Protein intake, Protein metabolism, Exercise training, Hypertrophy, Lean body mass

\section{Background}

Recommendations for dietary protein intake for healthy adults currently provide guidelines according to the total daily quantity of protein intake $[1,2]$, while new guidelines for athletes also note the importance of protein intake immediately after a resistance training session [3]. However, beyond total daily protein intake, a more balanced pattern of protein intake throughout the day can significantly improve net nitrogen retention of

\footnotetext{
* Correspondence: moore.daniel.r@gmail.com

'Nestlé Research Centre, Nestec Ltd, Lausanne, Switzerland

${ }^{2}$ Human Health and Nutritional Sciences, University of Guelph, 50 Stone

Road East, Guelph, Ontario N1G 2W1, Canada

Full list of author information is available at the end of the article
}

isonitrogenous diets in children and adults $[4,5]$, although this finding is not universal [6,7]. Moreover, tendencies toward a greater nitrogen balance and a lower whole-body protein breakdown have been observed in young women ingesting their daily protein intake in 4 balanced meals as compared to focussed in a single meal [8]. Collectively, these studies $[4,5,8]$ highlight the need to further investigate the impact different feeding patterns may have on protein kinetics to elucidate their physiological relevance for individuals aiming to maintain or increase lean body mass.

Given the known effect of dietary protein on the enhancement of muscle and whole-body protein synthesis [9] and the apparent advantage to balanced protein

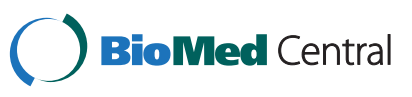


ingestion for whole-body nitrogen retention [5], we provided trained young men with isonitrogenous amounts of high quality protein that differed only in the pattern of ingestion to determine its effect on whole-body protein metabolism over a prolonged postprandial period. Knowing the dose-response relationship for optimally enhancing rested and post-exercise muscle protein synthesis $[10,11]$, the protein feeding patterns were designed to provide repeated feedings of surfeit $(40 \mathrm{~g})$, optimal $(20 \mathrm{~g})$, or insufficient $(10 \mathrm{~g})$ per meal protein intakes $[10,11]$. Based on previous findings $[10,11]$ and that skeletal muscle is the major storage reservoir for body amino acids, we hypothesized that whole-body net protein balance would be greatest with repeated feedings of $20 \mathrm{~g}$ of protein. The period of investigation was in the $12 \mathrm{~h}$ period immediately following a bout of resistance exercise to standardise and take advantage of the accentuated protein synthesis in the exercised muscle over this period [12].

\section{Methods}

Twenty-four male subjects participating in regular highintensity resistance training (4-6 times per week) were recruited for this study and provided their written, informed consent. The study conformed to the standards set by the Declaration of Helsinki, and carried the approval of the Human Research Ethics Committee of RMIT University and the Australian Institute of Sport.

After reporting to the laboratory to undergo a wholebody DEXA scan [13] and to determine one-repetition maximum (1-RM) bilateral knee extensor strength, subjects were provided with a standardized diet for the $72 \mathrm{~h}$ prior to the trial that provided an energy availability of $45 \mathrm{kcal} / \mathrm{kg}$ fat-free mass with a macronutrient contribution $1.5 \mathrm{~g}$ protein $/ \mathrm{kg} / \mathrm{d}$ and $4 \mathrm{~g}$ carbohydrate $/ \mathrm{kg} / \mathrm{d}$, respectively. Subjects were instructed to refrain from training and other vigorous physical activity during the $72 \mathrm{~h}$ period.

Subjects reported to the laboratory after a 10 -h overnight fast and provided a spot urine sample to determine baseline enrichment (see below). Following two warm up sets (5 repetitions at $60 \%$ and $70 \% 1-\mathrm{RM}$ ), subjects completed an acute bilateral leg extension exercise session ( $4 \times 10$ sets at $80 \% 1-R M$ with 3 min recovery between sets). Subjects were randomly allocated to receive a total of $80 \mathrm{~g}$ of whey protein isolate over $12 \mathrm{~h}$ in one of three different ingestion patterns: pulsed feeding (PULSE), 8x10g every $1.5 \mathrm{~h}$; intermediate feeding (INT), $4 \times 20 g$ every $3 \mathrm{~h}$; or bolus feeding (BOLUS), $2 \times 40 \mathrm{~g}$ every $6 \mathrm{~h}$. The BOLUS group was designed to simulate the ingestion of 2 large meals of the three meals one might consume in a given day. The first beverage of each group was consumed immediately after exercise and included

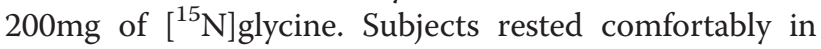

the laboratory and collected all urine over the complete 12-h period, which was pooled and stored at $-80^{\circ} \mathrm{C}$ until further analysis.

Urinary ammonia was isolated by cation exchange resin with the $\left[{ }^{15} \mathrm{~N}\right]$ enrichment determined by isotope ratio mass spectrometry [14]. Whole-body protein turnover (Q) was calculated using the $\left[{ }^{15} \mathrm{~N}\right]$ ammonia end-product method as described previously [15], which provides consistent rates over $12 \mathrm{~h}$ [16]. Concentrations of urinary urea and creatinine, the major nitrogen containing metabolites in urine, were measured by automated analyser at the Laboratoire Central de Chimie Clinique (Centre Hospitalier Universitaire Vaudois, Lausanne, Switzerland). Whole-body protein synthesis (S) and protein breakdown (B) were calculated as previously described [14] with estimated fecal and miscellaneous nitrogen losses of $0.95 \mathrm{~g} /$ $12 \mathrm{~h}$ and $0.69 \mathrm{~g} / 12 \mathrm{~h}$, respectively, which were based on half the daily excretion previously measured in strength athletes consuming a moderate protein diet [14]. Wholebody net protein balance (NB) was calculated as: $\mathrm{S}$ minus B. Data were expressed normalized to both whole body mass (BM) and fat- and bone-free (i.e., lean) body mass (LBM).

Data were analyzed using a one-way repeated measure analysis of variance (ANOVA) with Student Newman Keuls post-hoc analysis (Sigmastat V3.11). In the event of non-normal distribution, data were log-transformed prior to analysis. Statistical significance was established at $\mathrm{P}<0.05$ and all data are expressed as mean \pm standard deviation. It has been demonstrated previously that the $\left[{ }^{15} \mathrm{~N}\right]$ glycine-measured increase in NB is able to reasonably predict the training-induced increase in lean body mass in young men [17]. To account for possible subtle differences in the most physiologically meaningful variable of $\mathrm{NB}$, mean effect sizes and $90 \%$ confidence intervals (CI) were also calculated [18] to allow for probabilistic magnitude-based inferences between groups $[18,19]$. Quantitative chances of benefit and harm were assessed according to previously published cut-points using the smallest standardized change in the mean, as described in detail elsewhere $[18,19]$.

\section{Findings}

Due to a technical limitation, one subject in the INT group did not receive the appropriate feeding regimen and was removed from analysis. There was no difference in total $(82.0 \pm 6.4,77.5 \pm 7.9$, and $83.6 \pm 10.5 \mathrm{~kg})$ or lean body mass $(66.5 \pm 5.3,64.0 \pm 5.8$, and $66.2 \pm 5.4 \mathrm{~kg})$ for the participants in the PULSE, INT, and BOLUS groups, respectively. The $80 \mathrm{~g}$ of protein provided the subjects with $65 \pm 5 \%, 69 \pm 8 \%$, and $65 \pm 8 \%$ of the subject's mean daily protein intake (at $1.5 . \mathrm{g} / \mathrm{kg} / \mathrm{d}$ ) of the controlled diet in the PULSE, INT and BOLUS groups, respectively $(\mathrm{P}=0.39)$. 
When expressed relative to BM, whole-body nitrogen turnover (Q) was greater with PULSE as compared to BOLUS $(0.25 \pm 0.03$ vs $0.21 \pm 0.02 \mathrm{~g} \mathrm{~N} / \mathrm{kg} B W / 12 \mathrm{~h} ; \mathrm{P}<0.05)$ there was a trend towards a difference between PULSE and INT $(0.23 \pm 0.1 ; \mathrm{P}=0.08)$. PULSE resulted in a $\sim 19$ and $\sim 32 \%$ greater $(\mathrm{P}<0.05)$ whole-body protein synthesis (S) compared to INT and BOLUS, respectively (Figure 1A). There was no difference between INT and BOLUS for $\mathrm{S}(\mathrm{P}=0.17)$. Similarly, whole-body protein breakdown (B) was $\sim 51$ and $\sim 57 \%$ higher $(\mathrm{P}<0.05)$ with PULSE as compared to INT and BOLUS, respectively. However, there was no difference between INT and

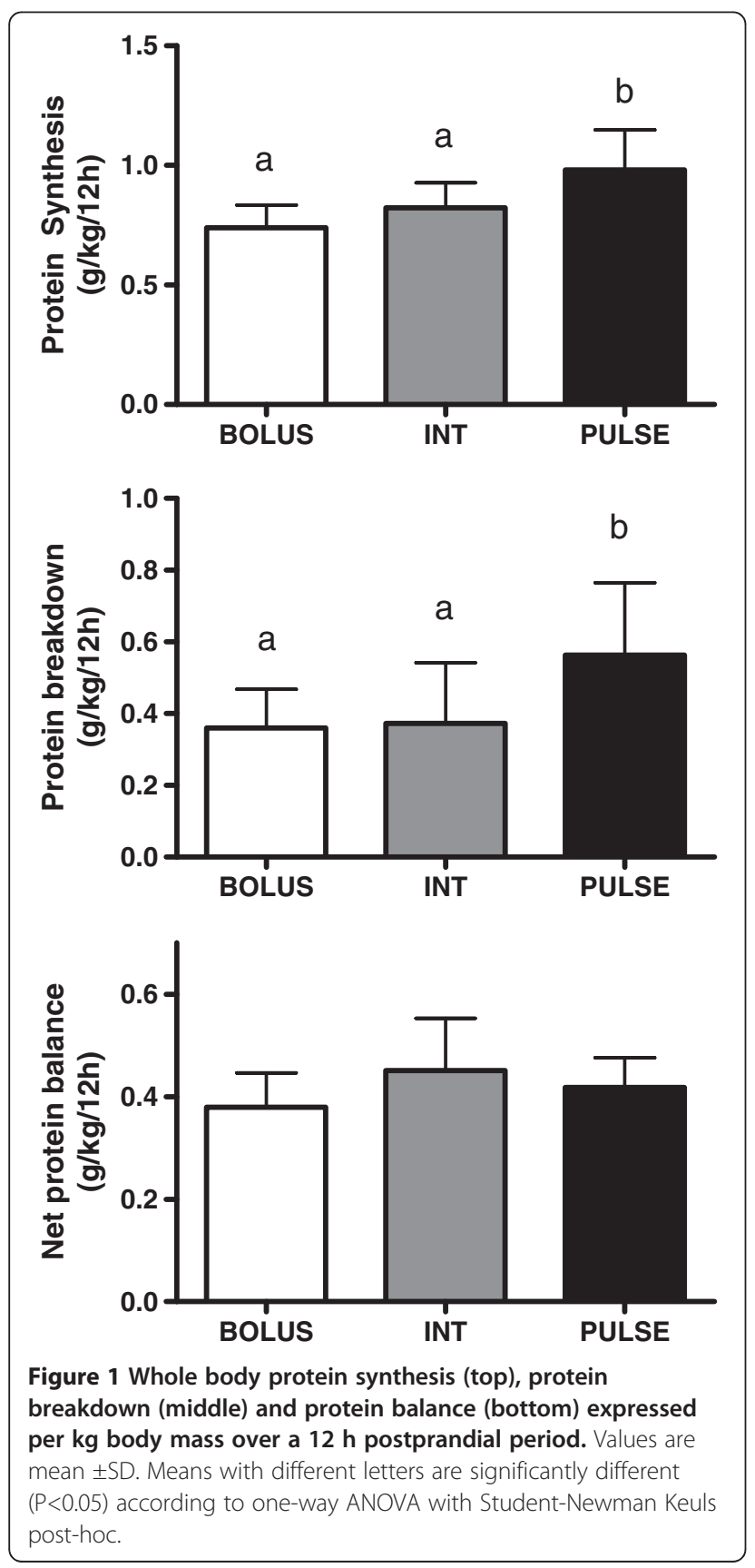

BOLUS for $\mathrm{B} \quad(\mathrm{P}=0.88)$. There were no differences $(\mathrm{P}=0.23)$ in $\mathrm{NB}$ between any conditions using an ANOVA. Analysis of the same data using probabilistic magnitude-based inferences revealed likely moderate and small positive effects for INT and PULSE, respectively, compared to BOLUS for NB (Table 1). Moreover, there was a possible small increase in NB for INT as compared to PULSE. When the data were expressed relative to lean body mass there was $\sim 21-25 \%$ increase in all rates $(\mathrm{Q}, \mathrm{S}, \mathrm{B})$ and $\mathrm{NB}$ due to the normalization to a lower total mass (i.e. lean vs whole body) but with similar differences and effects between groups (data not shown).

\section{Discussion}

We report here for the first time that manipulation of the pattern of intake of an identical amount of high quality protein over a 12-h post-prandial period following a bout of resistance exercise altered whole-body protein metabolism in trained young men. Our observation of larger protein feedings (i.e. $\geq 20$ g; INT and BOLUS) eliciting lower whole-body protein turnover than smaller (i.e. 10g; PULSE) repeated feedings may be related in part to a nutrient partitioning of dietary amino acids away from metabolism within non-muscle tissues with higher turnover rates (e.g. splanchnic region) towards skeletal muscle, which turns over relatively slowly [20]. We have proposed such a possibility previously in trained populations who presented lower rates of whole body protein turnover post-training but with concurrent enhancements in net balance and lean mass gains $[14,21]$. However, in light of the relative dearth of information on the physiological impact of different feeding patterns, substantiation of this hypothesis would require future studies that manipulate dietary ingestion patterns with concurrent measures of whole body and tissuespecific (e.g. muscle) protein metabolism.

A limitation of whole-body tracer methodologies is the inability to delineate tissue-specific changes in protein metabolism. However, the advantage is the ability to measure metabolism of the whole system to determine its net anabolic or catabolic state. The positive net balance in treatment groups is consistent with the anabolic effects of feeding and protein ingestion that would subsequently result in protein synthesis and protein

Table 1 Effect of feeding pattern on whole body net protein balance

\begin{tabular}{llll}
\hline Comparison & Mean effect \pm Cl & P-value & Qualitative inference \\
\hline PULSE - BOLUS & $0.59 \pm 0.87$ & 0.25 & Small increase likely \\
INT - BOLUS & $0.80 \pm 0.91$ & 0.15 & Moderate increase likely \\
INT - PULSE & $0.42 \pm 1.00$ & 0.46 & Small increase possible
\end{tabular}

Effect size thresholds: $<0.2$, trivial; $<0.6$, small; $<1.2$, moderate; $<2.0$, large. 
deposition within both rested and exercised lean tissues [11]. Regardless, despite this anabolic environment, subtle differences in feeding pattern on whole-body protein balance were evident in that repeated feedings of 10 and $20 \mathrm{~g}$ of protein resulted in a likely greater protein balance compared to larger $40 \mathrm{~g}$ feedings (Table 1 ). The physiological basis for these differences may be related in part to lower amino acid oxidation that would occur with the smaller (i.e. $\leq 20 \mathrm{~g}$ ) repeated feedings [11]. In contrast, the possibly greater protein balance with the $20 \mathrm{~g}$ as compared to the $10 \mathrm{~g}$ feedings may be related to a more efficient stimulation of protein synthesis in both rested and exercised skeletal muscle and hence deposition of dietary amino acids within that tissue [11,22,23]. In light of our previous observations of a reasonable agreement between tracer-derived increases in whole-body net protein balance (measured by oral $\left[{ }^{15} \mathrm{~N}\right]$ glycine) and training-induced increases in lean body mass [14], the present data could suggest that individuals wishing to enhance or maintain lean body mass could obtain a benefit from the repeated ingestion of moderate amounts of dietary protein at regular intervals throughout the day. This concept has been raised previously for athletes [3], may have preliminary support in general populations [24], and represents, we propose, a fruitful area of further study.

\section{Conclusions}

In conclusion, despite equivalent total protein intake, whole-body protein synthesis and breakdown are greatest when small (i.e. 10g) as compared to larger (i.e. $\geq 20 \mathrm{~g}$ ) protein feedings are consumed at regular intervals during a $12 \mathrm{~h}$ postprandial period after a bout of exercise. However, whole-body protein balance tended to be greatest with moderate $20 \mathrm{~g}$ feedings every $3 \mathrm{~h}$, which may have implications for individuals aiming to enhance whole-body anabolism including lean body mass accrual with training. Collectively, our data highlight that the acute pattern, and not only the total amount, of ingested protein should be considered when determining feeding strategies to alter whole-body protein metabolism.

\footnotetext{
Abbreviations

PULSE: Protein ingestion pattern of $10 \mathrm{~g}$ of protein at $1.5 \mathrm{~h}$ intervals for $12 \mathrm{~h}$ (i.e. 8 feedings); INT: Protein ingestion pattern of $20 \mathrm{~g}$ of protein at $3 \mathrm{~h}$ intervals for $12 \mathrm{~h}$ (i.e. 4 feedings); BOLUS: Protein ingestion patter of $40 \mathrm{~g}$ of protein at $6 \mathrm{~h}$ intervals for $12 \mathrm{~h}$ (i.e. 2 feedings); Q: Whole body nitrogen turnover; S: Whole body protein synthesis; $\mathrm{B}$ : Whole body protein breakdown; NB: Whole body net protein balance; LBM: Lean body mass; BM: Body mass.
}

\section{Competing interests}

Some of the authors (MC, and JPG) are or were (DRM, TS) employees of Nestec Ltd., which is a subsidiary of Nestlé Ltd. and provides professional assistance, research, and consulting services for food, dietary, dietetic, and pharmaceutical products of interest to Nestlé Ltd. The authors declare no financial conflicts of interest.

\section{Authors' contributions}

DRM, VGC, TS, SMP, LMB, and JAH designed the study and obtained the grant. JLA, VGC, LMB, and JAH carried out the study. DRM, JLA, VGC, MC, and JPG conducted laboratory analysis. DRM, SMP, and JAH performed statistical analysis and wrote the manuscript. All authors read and approved the final manuscript.

\section{Acknowledgements}

We would like to thank Liz Broad and Nikki Jeacocke for their help in dietary planning, Stéphane Pinaud for coordination of the urinary metabolite analysis, and the subjects for their time and effort. The whey protein isolate was graciously provided by Musashi Australia. Funding for this study was provided by Australian Research Council Grant L100100010 through partnerships with RMIT, McMaster University, the Australian Institute of Sport, and Nestec Ltd.

\section{Author details}

${ }^{1}$ Nestlé Research Centre, Nestec Ltd, Lausanne, Switzerland. ${ }^{2}$ Human Health and Nutritional Sciences, University of Guelph, 50 Stone Road East, Guelph, Ontario N1G 2W1, Canada. ${ }^{3}$ Exercise and Nutrition Research Group, School of Medical Sciences, RMIT University, Melbourne, VIC, Australia. ${ }^{4}$ Canadian Sport Centre - Pacific, Victoria, British Columbia, Canada. ${ }^{5}$ Department of Kinesiology, McMaster University, Hamilton, ON, Canada. ${ }^{6}$ Sports Nutrition, Australian Institute of Sport, Belconnen, ACT, Australia.

Received: 18 July 2012 Accepted: 14 October 2012

Published: 16 October 2012

\section{Reference}

1. Rodriguez NR, Di Marco NM, Langley S: American College of Sports Medicine position stand. Nutrition and athletic performance. Med Sci Sports Exerc 2009, 41:709-731.

2. : Protein and amino acid requirements in human nutrition. World Health Organ Tech Rep Ser 2007, :1-265.

3. Phillips SM, van Loon LJ: Dietary protein for athletes: From requirements to optimum adaptation. J Sports Sci 2011, 29(Suppl 1):S29-S38.

4. Barja I, Araya H, Munoz P, Vega L, Arteaga A, Tagle MA: Effect of spacing protein intake on nitrogen balance in normal children. Am J Clin Nutr 1972, 25:506-511.

5. Leverton RM, Gram MR: Nitrogen excretion of women related to the distribution of animal protein in daily meals. J Nutr 1949, 39:57-65.

6. Leverton RM, Gram MR, Chaloupka M: Effect of the time factor and calorie level on nitrogen utilization of young women. J Nutr 1951, 44:537-545.

7. Taylor YS, Young VR, Murray E, Pencharz PB, Scrimshaw NS: Daily protein and meal patterns affecting young men fed adequate and restricted energy intakes. Am J Clin Nutr 1973, 26:1216-1223.

8. Arnal MA, Mosoni L, Boirie Y, Houlier ML, Morin L, Verdier E, Ritz P, Antoine $J M$, Prugnaud J, Beaufrere B, et al: Protein feeding pattern does not affect protein retention in young women. J Nutr 2000, 130:1700-1704.

9. Burd NA, Tang JE, Moore DR, Phillips SM: Exercise training and protein metabolism: influences of contraction, protein intake, and sex-based differences. J Appl Physiol 2009, 106:1692-1701.

10. Cuthbertson D, Smith K, Babraj J, Leese G, Waddell T, Atherton P, Wackerhage $H$, Taylor PM, Rennie MJ: Anabolic signaling deficits underlie amino acid resistance of wasting, aging muscle. FASEB J 2005, 19:422-424

11. Moore DR, Robinson MJ, Fry JL, Tang JE, Glover El, Wilkinson SB, Prior T, Tarnopolsky MA, Phillips SM: Ingested protein dose response of muscle and albumin protein synthesis after resistance exercise in young men. Am J Clin Nutr 2009, 89:161-168.

12. Tang JE, Perco JG, Moore DR, Wilkinson SB, Phillips SM: Resistance training alters the response of fed state mixed muscle protein synthesis in young men. Am J Physiol Regul Integr Comp Physiol 2008, 294:R172-R178.

13. Nana A, Slater GJ, Hopkins WG, Burke LM: Effects of daily activities on dual-energy X-ray absorptiometry measurements of body composition in active people. Med Sci Sports Exerc 2012, 44:180-189.

14. Hartman JW, Moore DR, Phillips SM: Resistance training reduces wholebody protein turnover and improves net protein retention in untrained young males. Appl Physiol Nutr Metab 2006, 31:557-564. 
15. Grove $G$, Jackson AA: Measurement of protein turnover in normal man using the end-product method with oral [15N]glycine: comparison of single-dose and intermittent-dose regimens. Br J Nutr 1995, 74:491-507.

16. Tarnopolsky MA, Atkinson SA, MacDougall JD, Chesley A, Phillips S, Schwarcz HP: Evaluation of protein requirements for trained strength athletes. J Appl Physiol 1992, 73:1986-1995.

17. Hopkins WG: A spreadsheet for analysis of straightforward controlled trials. Sportscience 2003, 7. sportsci.org/jour/03/wghtrials.htm.

18. Batterham AM, Hopkins WG: Making meaningful inferences about magnitudes. Int I Sports Physiol Perform 2006, 1:50-57.

19. Hopkins WG: Probabilities of Clinical or Practical Signficance. Sportscience 2002, 6. sportsci.org/jour/0201/wghprob.htm.

20. Tessari P, Garibotto G, Inchiostro S, Robaudo C, Saffioti S, Vettore M, Zanetti $M$, Russo R, Deferrari G: Kidney, splanchnic, and leg protein turnover in humans. Insight from leucine and phenylalanine kinetics. J Clin Invest 1996, 98:1481-1492

21. Moore DR, Del Bel NC, Nizi Kl, Hartman JW, Tang JE, Armstrong D, Phillips SM: Resistance training reduces fasted- and fed-state leucine turnover and increases dietary nitrogen retention in previously untrained young men. J Nutr 2007, 137:985-991.

22. Moore DR, Tang JE, Burd NA, Rerecich T, Tarnopolsky MA, Phillips SM: Differential stimulation of myofibrillar and sarcoplasmic protein synthesis with protein ingestion at rest and after resistance exercise. $J$ Physiol 2009, 587:897-904.

23. Tipton KD, Borsheim E, Wolf SE, Sanford AP, Wolfe RR: Acute response of net muscle protein balance reflects 24 -h balance after exercise and amino acid ingestion. Am J Physiol Endocrinol Metab 2003, 284:E76-E89.

24. Loenneke JP, Balapur A, Thrower AD, Syler G, Timlin M, Pujol TJ: Short report: Relationship between quality protein, lean mass and bone health. Ann Nutr Metab 2010, 57:219-220.

doi:10.1186/1743-7075-9-91

Cite this article as: Moore et al:: Daytime pattern of post-exercise protein intake affects whole-body protein turnover in resistance-trained males. Nutrition \& Metabolism 2012 9:91.

\section{Submit your next manuscript to BioMed Central and take full advantage of:}

- Convenient online submission

- Thorough peer review

- No space constraints or color figure charges

- Immediate publication on acceptance

- Inclusion in PubMed, CAS, Scopus and Google Scholar

- Research which is freely available for redistribution 